\title{
AlliCin HAS SIGNIFICANT EFFECT ON AUTOIMMUNE ANTI-ISLET CELL ANTIBODIES IN TYPE 1 DIABETIC RATS
}

\author{
Muhamed Osman, Ariza Adnan, Nor Salmah Bakar, Fatma Alashkham
}

Centre of Pathology, Diagnostic and Research Laboratory, Faculty of Medicine, Universiti Teknologi MARA (UiTM), Sg. Buloh Campus, Selangor, Malaysia

\begin{abstract}
The research purpose was to experimentally investigate the effect of allicin administration on the levels of main type 1 diabetes (IDDM) autoantibodies which are antiislet cell antibodies (ICA) with an attempt to find a relation between this immunological effect and histological and/or biochemical findings. We have evaluated, with the help of ELISA kits, the levels of ICA and serum insulin in male Sprague-Dawley rats with Streptozotocin-induced IDDM in addition to pancreatic histological findings. The four groups (6 rats each) under study received or not different intraperitoneal doses of allicin for a period of 30 days. Daily intraperitoneal administration of allicin (either at as low dose of $8 \mathrm{mg} / \mathrm{kg}$ or high dose of $16 \mathrm{mg} / \mathrm{kg}$ ) for up to 30 days to type 1 diabetic rats effectively reduces levels of anti-islet cell antibodies and in addition, reduced the level of insulin due to damaged Langerhans islet cell was significantly increased in the serum due to a repairing tissue process in pancreatic tissues. These experimental results suggest that allicin treatment has a therapeutic protective effect against autoimmune reactions occurring in IDDM. The data may provide new strategies for using allicin to be recommended as an excellent candidate in the clinical management, control, and prevention of IDDM.
\end{abstract}

Key words: allicin, garlic, type 1 diabetes mellitus, anti-islet cell antibody, serum insulin.

\section{Introduction}

Type 1 diabetes mellitus or insulin-dependent diabetes mellitus (IDDM) is an autoimmune disease process in which pancreatic islet $\beta$-cells are targeted for destruction by an aberrant host immune system [1]. This process involves both the cellular and humoral branches of the immune system, with the generation of isletspecific T-cell reactivity, as well as autoantibodies directed against islet cell antigens [1].

The disease process in IDDM is primarily caused by the destruction of pancreatic $\beta$ cells that is thought to result mainly from the action of T-lymphocytes; the key players in autoimmune disease development [2]. Meanwhile, in subjects newly diagnosed with IDDM, up to $90 \%$ have autoantibodies to islet cell antibodies ICA [2]. These autoantibodies appear during the pre- clinical period of $\beta$-cell destruction before the clinical manifestation of diabetes [2]. The hallmark of the autoimmunity of IDDM is the presence of circulating ICA autoantibodies, they are thought to signal a T-cell mediated immune response which sets the stage for $\beta$ cell destruction [2]. However, multiple environmental and genetic factors make the immune cells, particularly $\mathrm{T}$ lymphocytes, to invade islet $\beta$ cells and cause pancreatic inflammation [3].

Experimental studies on animals, especially rats, showed that these animals develop a form of autoimmune diabetes that resembles human IDDM [4]. Studies with an animal model have established that isletinfiltrating cell-reactive T-cells are the major effectors of $\beta$-cell damage. However, other immune system cells are also crucial in the disease development. Among these cells, B-cells are essential in the onset and progression 
of type 1 diabetes $[5,6]$, and although it is not fully understood when and how these cells participate in IDDM, it is known that they produce ICA autoantibodies against many $\beta$-cell autoantigens [6] and act as antigen-presenting cells [7]. On the other hand, the production of specific ICA autoantibodies directly correlates with the progression of IDDM in both humans and laboratory animals [7].

Due to the increasing worldwide prevalence and financial burden of diabetes, it has become increasingly important to find pharmacological remedies to alleviate the symptoms and complications of these conditions. In particular, the use of natural remedies such as garlic and its major component allicin, has become popular as both preventative and treatment alternatives [1].

Allicin is a major component of garlic (Allium sativum) and a precursor of many secondary products formed in aged garlic and crushed garlic preparations. The antimicrobial [8, 9], antitumor [10-12], antifungal [13], and antigenotoxic [14], activities of allicin have been reported. Meanwhile, various researches have indicated that garlic and allicin have inhibitory immunomodulatory action [15], they modulate immune responses, enhance humoral immunity and minimize immunological stress, and thus affect growth performance most positively [15]. Studies demonstrated that garlic enhances natural killer (NK) activity and T-lymphocyte proliferation $[15,16]$.

Many studies have examined the hypoglycemic effect of allicin in both types of DM [17-20], but till now the mechanism has not been discussed with regard to IDDM while the probable mechanism underlying garlic and allicin hypoglycemic effects in type 2 diabetes most likely is increased insulin secretion and sensitivity $[21,22]$.

To date, there have been no successful treatment interventions that have been found to delay the onset of type 1 diabetes. Thus, our present study was carried out in UiTM Malaysia, for the first time according to our knowledge to investigate the effect of allicin administration on the levels of main IDDM autoantibodies which are anti-islet cell antibodies with an attempt to find a relation between this immunological effect and histological and/or biochemical findings.

\section{Material and methods}

\section{Experimental animals}

Twenty four male Sprague-Dawley rats with an average weight of 150-250 $\mathrm{g}$ and an average age of 12-16 weeks were used throughout the experiment, obtained from Nano Life Quest Company. The rats were acclimatized for a period of 21 days. Standard environmental conditions such as temperature $\left(20-22^{\circ} \mathrm{C}\right)$, relative humidity (45-55\%) and $12 \mathrm{hrs} \mathrm{dark/light} \mathrm{cy-}$ cles were maintained. The animals were fed daily with rodent pellet diet and tap water ad libitum under strict hygienic conditions.

Ethical clearance for performing the experiment on animals was approved by the Animal Care and Use Committee (ACUC), Faculty of Medicine, Universiti Teknologi MARA (UiTM) Malaysia that conforms to the Guide for the Care and Use of Laboratory Animals [20] and all efforts were made to minimize animal suffering and the number of animals used.

\section{Chemicals}

Streptozotocin (STZ) used in the present study was purchased from Nano Life Quest Company; Allicin (2-propene-1-sulfinothioc acid S-2-propenyl ester; thio-2-propene-1-sulfinic acid S-allyl ester) was purchased from Nano Life Quest Company. The allicin was administered once a day by intraperitoneal injection (i.p.) at a dose of $8 \mathrm{mg} / \mathrm{kg}$ and $16 \mathrm{mg} / \mathrm{kg}$ for 30 days.

\section{Induction of type 1 diabetes mellitus and treatment of rats}

A single injection of STZ is widely used to generate a rat model of type 1 diabetes, which results from the selective toxicity of STZ towards the insulin-producing $\beta$-cells in pancreatic islets $[23,24]$. IDDM was induced in an overnight fasted animal group by intraperitoneal injection with a single dose of STZ $(65 \mathrm{mg} / \mathrm{kg}$ body weight) (Sigma). This dose of STZ lies within the range used in most of studies to produce IDDM, in which blood glucose levels are 3-4 times higher than normal, by causing a substantial depletion of pancreatic insulin [25]. Streptozotocin was dissolved in sodium citrate buffer solution (PH 4.5) immediately before use. The development of IDDM was confirmed by the presence of hyperglycemia with blood glucose above $13.9 \mathrm{mmol} / \mathrm{l}(250 \mathrm{mg} / \mathrm{dl})$, which lasted for at least three days. The rats were divided into four groups comprising 6 rats each. Group A [GA; control group, rats were injected with an equal volume of vehicle (citrate buffer, $65 \mathrm{mg} / \mathrm{kg}$ body weight)]; Group B (GB; untreated STZ-diabetic rats); Group C (GC; STZ-diabetic rats treated with $8 \mathrm{mg} / \mathrm{kg}$, i.p., allicin); Group D (GD; STZ-diabetic rats treated with $16 \mathrm{mg} / \mathrm{kg}$, i.p., allicin).

The treatment by allicin was started for a period of 30 days. During this period, all animals had free access to standard diet and water until $6 \mathrm{pm}$. None of the rats was treated with insulin at any time during the experiment. Animals were sacrificed on the $30^{\text {th }}$ day of experiment immediately after measuring blood glucose [24]. Blood glucose levels were tested every morning (at $8 \mathrm{am}$ ). Blood was collected from the tail of fasting $(14 \mathrm{~h})$ animals. A drop of blood was used for the blood glucose test with the help of a One Touch Glucometer GX. 


\section{Laboratory tests}

On the last day ( $30^{\text {th }}$ day) and after completion of the experimental protocols, blood samples were collected from overnight fasting rats by sacrificing each diabetic and control rats. The animals were anesthetized in a chamber containing diethyl ether. A cardiac puncture was done using a heparin syringe and blood was collected into a heparin containing container. Immediately after collection, $2.0 \mathrm{ml}$ of blood was transferred into a fresh tube and centrifuged at $3000 \mathrm{rpm}$ for 10 minutes. The serum was collected and stored at $-80^{\circ} \mathrm{C}$ until serological analysis.

Serum was assayed for anti-islet cell antibodies (ICA) and serum insulin using enzyme-linked immunosorbent assay (ELISA) using commercially available kits (USCNK, CHINA). Also pancreatic tissues were collected for histological examination.

\section{Summary of histopathological procedures}

Pancreatic tissues [26] were harvested from the animals and they were fixed in $10 \%$ neutral formalin solution, embedded in paraffin, and then stained with hematoxylin and eosin ( $\mathrm{HE})$. The preparations were evaluated by means of a bright-field microscope and photographed (Optiphot 2; Nikon, Tokyo, Japan).

\section{Statistical analysis}

The data are expressed as mean \pm SE with ' $n$ ' referring to the number of rats used. Two-way analysis of variance (ANOVA) was carried out using SPSS 16 software to assess the overall effects and interaction of treatment and time on parameters and followed by repeated one-way analysis of variance (ANOVA) with a post hoc least significant difference (LSD) test to determine the effect of treatment on differences among means when the analysis of variance indicated a significant result. $\mathrm{P}<0.05$ was taken to indicate significance.

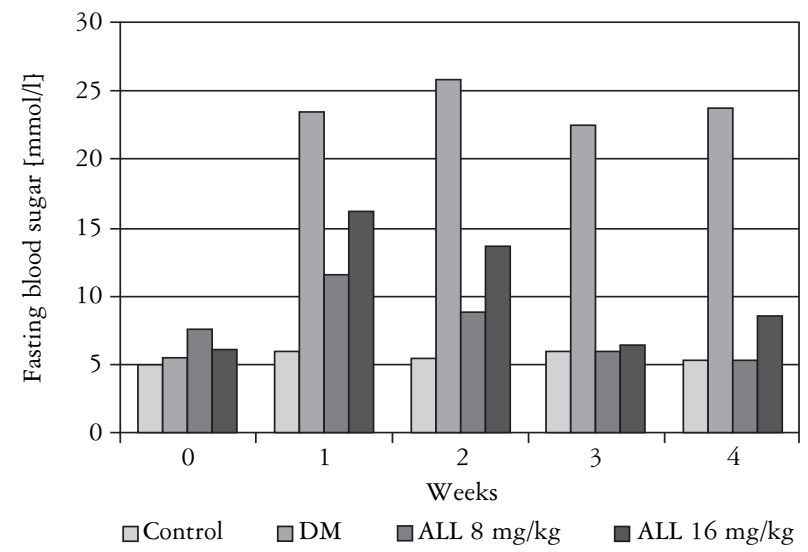

Fig. 1. Fasting blood sugar for all rat groups with/without treatment

\section{Results}

\section{Immunological and biochemical findings}

The diabetic animals exhibited consistent hyperglycemia (Fig. 1). Meanwhile, allicin treatment caused a decrease in the elevated serum glucose (Fig. 1), and however, Fig. 2 demonstrated the changes to the body weight of all rat groups during the experiment. Rat body weight was elevated by treatment in both allicin doses.

There is an increase $(\mathrm{P}=0.001)$ in the lowered serum insulin concentrations in STZ-induced diabetic rats by the end of the experiment (Fig. 3).

After induction of IDDM, the diabetic animals showed an increase in the levels of anti-islet cell auto antibodies ICA (Fig. 4), however, by the end of the experiment the allicin treatment specially in high doses diabetic group significantly $(\mathrm{P}=0.001)$ decreased the elevated ICA levels (Fig. 4).

\section{Histological findings}

The histological findings in the histological sections of pancreatic tissues stained with $\mathrm{H} \& \mathrm{E}$ in the normal control rats (GA) showed normal structure (Fig. 5A). The islets of Langerhans appeared regular in shape surrounded by a thin capsule of connective tissue with lightly stained round clusters of cells embedded in the exocrine tissue. While in STZ diabetic rats with no treatment (GB) (Fig. 5B), the findings were degenerative and necrotic changes, and shrinkage in the islets of Langerhans. The islets were relatively small, atrophied, and showed a reduction in the number of polygonal islet cells. The nucleus of necrotic cells indicated either pyknosis or marginal hyperchromasia. There was mostly hydropic degeneration and degranulation in the cytoplasm of the degenerative and necrotic cells, while some of the cells with a pyknotic nucleus had a dark eosinophilic cytoplasm.

Meanwhile, islets of Langerhans in low dose allicin treated rats $(8 \mathrm{mg} / \mathrm{kg})$ (GC) (Fig. 5C) revealed light-

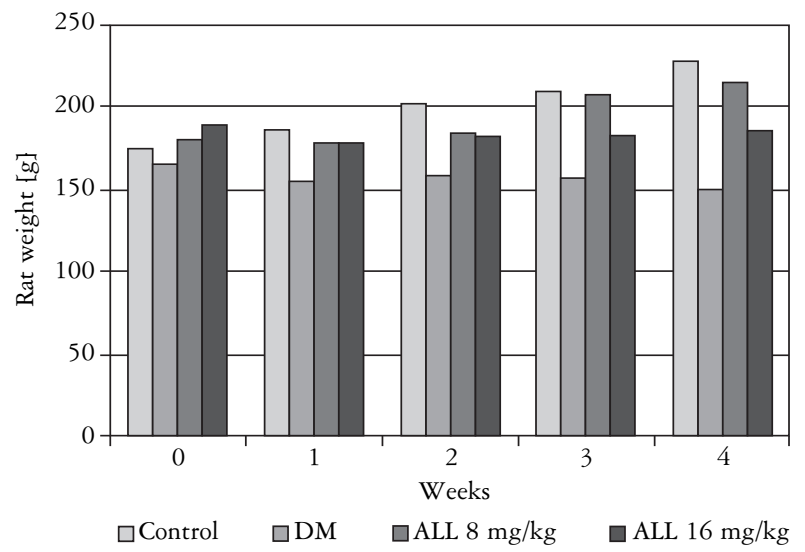

Fig. 2. Body weight for all rat groups with/without treatment 
Mean values of serum insulin levels in all groups

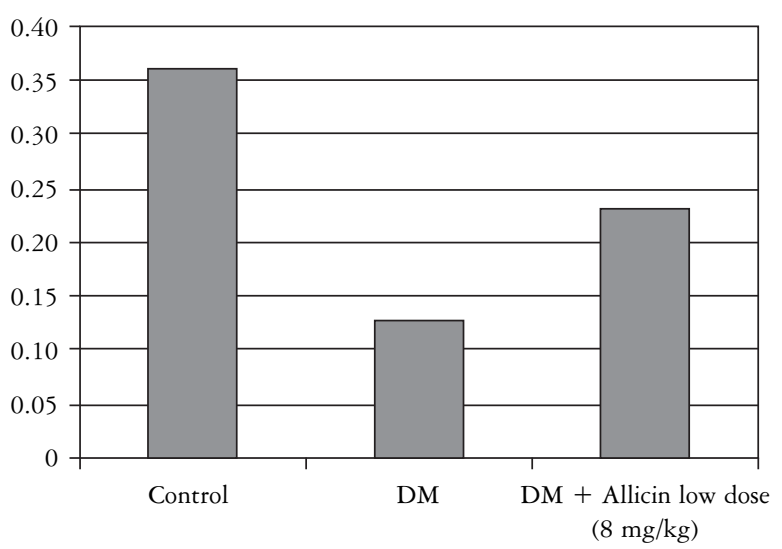

Fig. 3A. Effect of allicin (low dose $8 \mathrm{mg} / \mathrm{kg}$ ) administration on serum insulin levels

Mean values of ICA levels in all groups

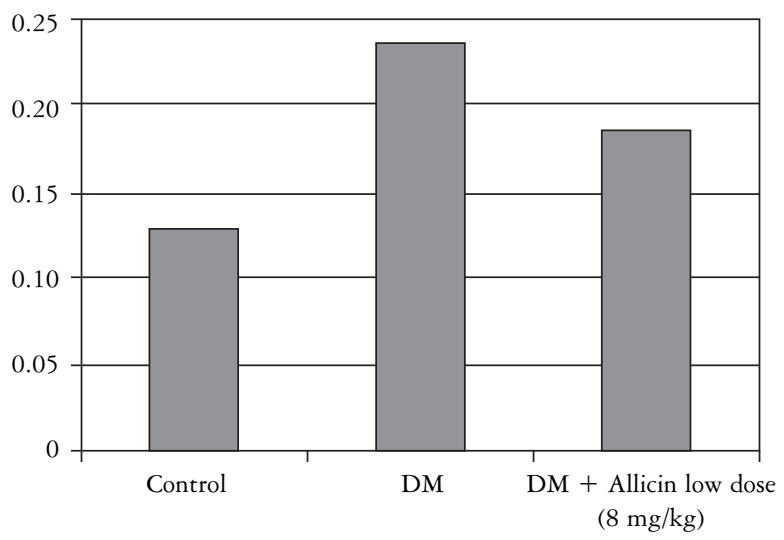

Fig. 4A. Effect of allicin (low dose $8 \mathrm{mg} / \mathrm{kg}$ ) administration on the ICA levels

ly stained, elongated islets of similar size to those seen in the control group (GA) but still some islets showed disrupted cytoplasm in certain areas displaying small vacuoles, infiltration of the islet by the exocrine acinar. This figure will be much better with a high dose of allicin in the last group (GD) (Fig. 5D) since there was protection to the majority of the Langerhans islet cells which appeared regular in shape and so much similar to the normal shape in GA.

\section{Discussion}

This study demonstrates for the first time, to our knowledge, the effect of allicin, the active component of garlic on the islet cell autoantibodies (ICA) production in IDDM with additional biochemical and histological evidence.

Our principal findings are: 1) daily intraperitoneal administration of allicin (either low dose of $8 \mathrm{mg} / \mathrm{kg}$ or high dose of $16 \mathrm{mg} / \mathrm{kg}$ ) for up to 30 days to type 1 diabetic rats effectively reduces levels of anti-islet cell antibod-

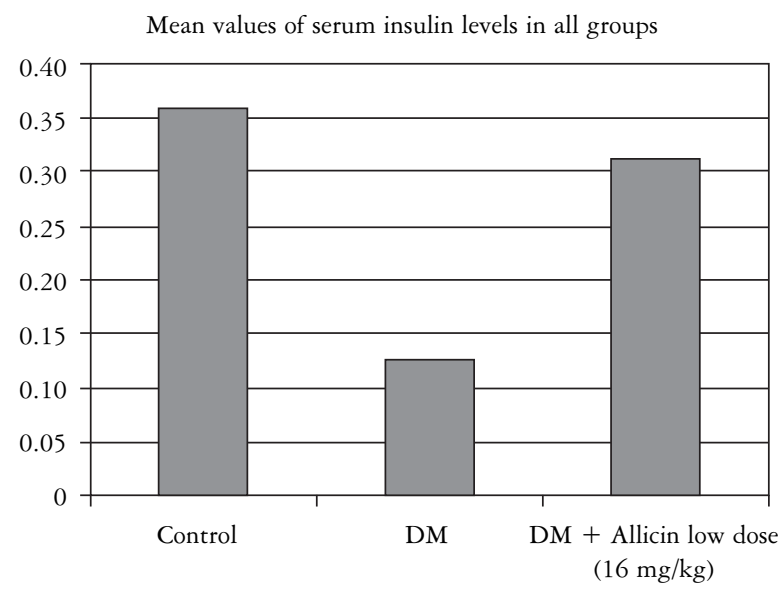

Fig. 3B. Effect of allicin (high dose $16 \mathrm{mg} / \mathrm{kg}$ ) administration on serum insulin levels

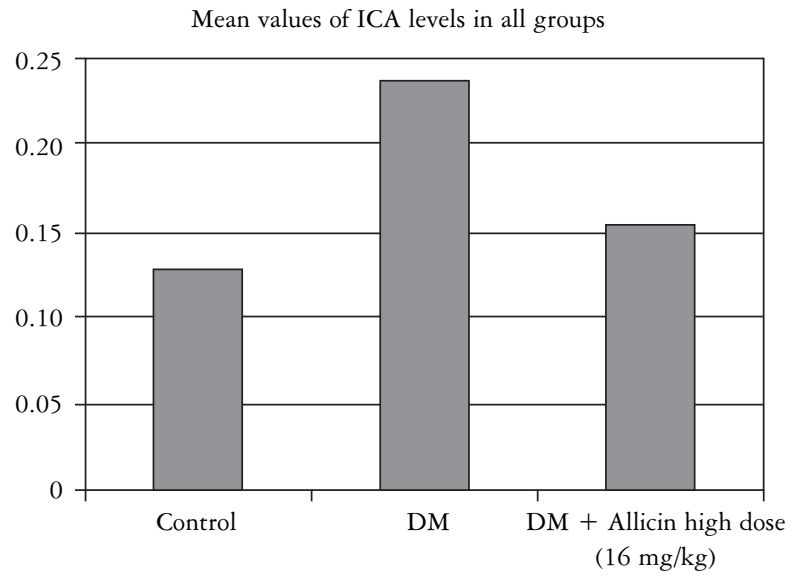

Fig. 4B. Effect of allicin (high dose $16 \mathrm{mg} / \mathrm{kg}$ ) administration on the ICA levels

ies which are the main antibodies produced in the autoimmune process of the disease; 2) the elevated hyperglycemia was reduced under the effect of allicin; and 3) reduced level of insulin due to damaged Langerhans islet cell was significantly increased in the serum due to the repairing tissue process due to allicin administration.

While the therapeutic anti-diabetic effects of the whole garlic or allicin alone on type 2 diabetes mellitus are numerous and well-documented, evidence presented in this study actually shows a novel immunomodulatory effect of allicin in IDDM of STZ-induced diabetic rats. This finding is made more interesting by the fact that many studies $[17-20]$ have shown that allicin is hypoglycemic in both types of diabetes through biochemical evidence while in this study we have proved that allicin has a significant effect on the production of main autoimmune antibodies in IDDM that lead to affect and stop the disease autoimmune process of IDDM.

Studies have determined that the consequence of ICA autoantibodies in IDDM is a destruction 

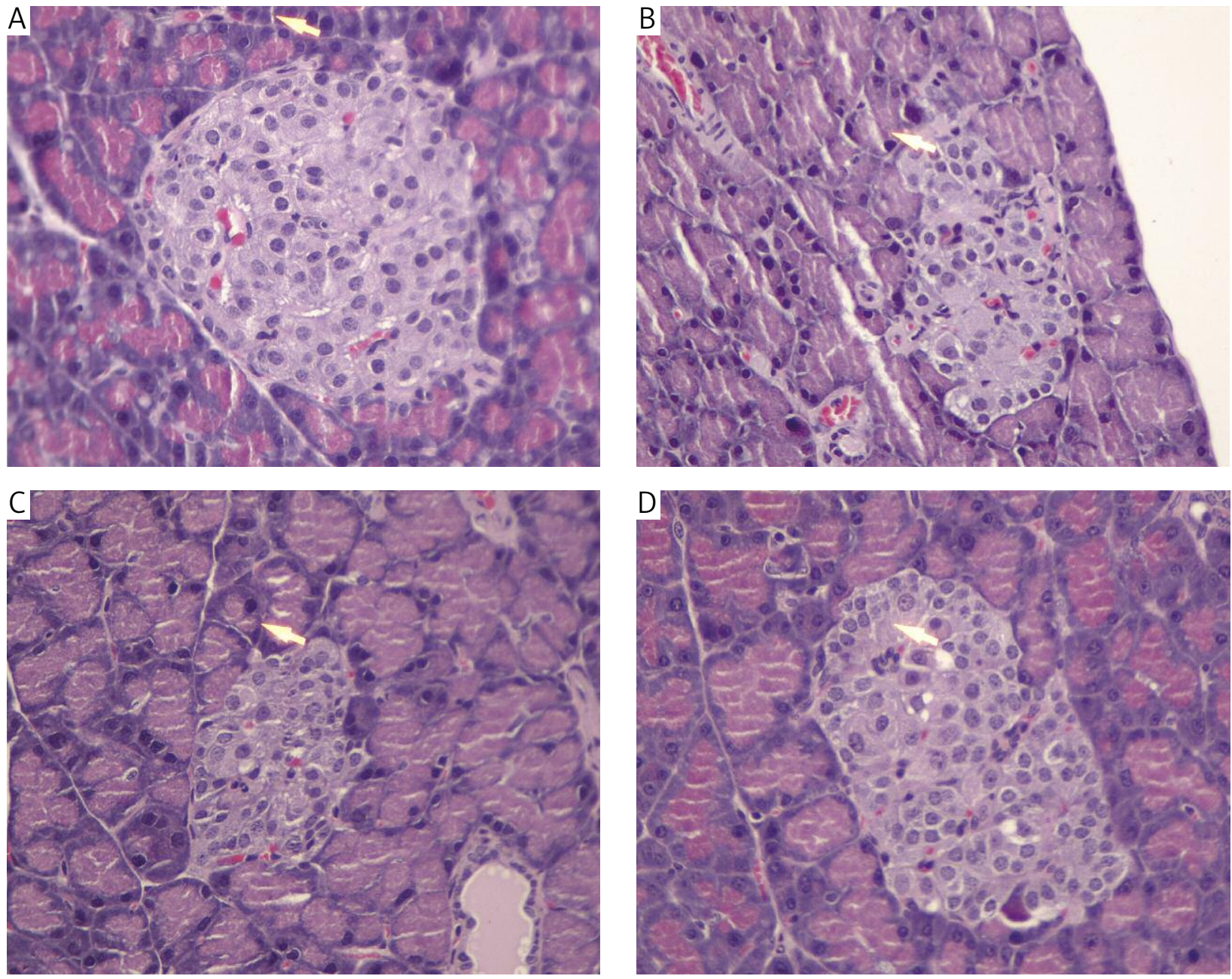

Fig. 5. Microphotographs of pancreatic tissue. HE 420. A - control group, showing normal cells in the islets of Langerhans; B - diabetic group. Shrunken islets of Langerhans displaying degenerative and necrotic changes in diabetic rats with no treatment; $\mathrm{C}$ - allicin-treated group $(8 \mathrm{mg} / \mathrm{kg})$ : Allicin protected the majority of cells in the islets of Langerhans; D - allicin-treated group $16 \mathrm{mg} / \mathrm{kg}$; looks like a normal control group)

of the insulin-producing $\beta$ cells of the islets of Langerhans' cells and an absence or deficiency of circulating insulin [26]. The autoimmune attack of these antibodies appears to destroy $\beta$ cells selectively $[1,26]$. Researchers have considered that ICA serum autoantibodies are an important hallmark of this disease, and assays for these islet cell antibodies have facilitated the investigation and understanding of several facets in the pathogenesis of autoimmune diabetes. Their applications have begun to extend into clinical practice and have opened new avenues for early preclinical prediction and preventive prophylaxis in IDDM [5-26].

The immunomodulatory and immunostimulatory effects of allicin alone or within garlic were reported in many studies. It potentially induces lymphocyte proliferation and macrophage phagocytosis, stimulates the infiltration of macrophages and lymphocytes in transplanted tumors, induces splenic hypertrophy, stimulates release of interleukin-2, tumor necrosis factor $\alpha$ and interferon- $\gamma$ and enhances natural killer cell and lymphokine-activated killer cell activity. These activities reflect effective stimulation of the immune response $[27,28]$. Meanwhile, because certain diseases can be caused by immune dysfunction, modification of immune functions by garlic may contribute to the treatment and prevention of diseases. Thus, some pharmacologic effects of garlic might be mediated through immunomodification [27-30].

The present study showed additional biochemical evidence apart from that of the immunological effect of allicin. This result indicates that allicin affects body weight, blood glucose and insulin level. However, most of the studies showed that garlic can reduce blood glucose levels in diabetic mice, rats and rabbits [31-34]. It is not clear how garlic and allicin actually work in alleviating hyperglycemia. The hypoglycemic action of allicin could possibly be due to an increase in pancreatic secretion of insulin from $\beta$-cells, release of bound insulin or enhancement of insulin sensitivity. It has been previously suggested that allicin can enhance serum in- 
sulin by effectively combining with compounds like cysteine [35].

In the current study we examined the effects of allicin on cell damage in IDDM in STZ-induced rats in concordance with immunological and biochemical effects. STZ is cytotoxic to $\beta$-cells [36]. Although the $\beta$-cell cytotoxic action of STZ is not fully understood, it is thought to be mediated by the inhibition of free radical scavenger-enzymes, which enhances the production of superoxide radicals [36]. In the present study, almost all of the insulin-producing $\beta$-cells were degranulated, degenerated, or necrosed in the STZ-treated rats (Fig. $3 \mathrm{~B}$ ), which led to a decrease in insulin secretion and an increase in blood glucose levels. Streptozotocin induced a significant decrease in the area of insulin immunoreactive $\beta$-cells. Streptozotocin causes IDDM. In our study, allicin treatment protected the majority of the Langerhans islet cells. Nevertheless, in the low doses $(8 \mathrm{mg} / \mathrm{kg})$ we observed light hydropic degeneration, degranulation, and necrosis in some cells (Fig. 5C) but with high dose $(16 \mathrm{mg} / \mathrm{kg})$, allicin prevented degeneration of $\beta$-cells and a picture like normal appeared (Fig. 5D). Allicin treatment increased the area of insulin immunoreactive $\beta$-cells significantly.

The goals of treatment of autoimmune diseases are to reduce symptoms, control the autoimmune process and maintain the body's ability to fight disease [37]. Some patients may need supplements to replace a hormone (like insulin injections in IDDM [38] or immunosuppressive medicines include corticosteroids to control or reduce the immune system's response, but these medicines often cause a lot of side effects [37]. Our findings suggest that allicin treatment has a therapeutic protective effect against autoimmune reactions in IDDM and immune defense in IDDM can be significantly improved by the administration of allicin. The data may provide new strategies for using allicin to be recommended in the clinical management, control, and prevention of IDDM.

This research was completely funded by an international grant from the Libyan Embassy in Malaysia (RMI/INT 3/2011). The authors would like to thank all staff of the IMMB institute and CPDRL Laboratories, Faculty of Medicine, UiTM Malaysia for technical help.

The authors declare no conflict of interest.

\section{References}

1. American Diabetes Association. Diagnosis and classification of diabetes mellitus. Diabetes Care 2008; 31: 55-60.

2. Notkins AL, Lernmark A. Autoimmune type 1 diabetes: resolved and unresolved issues. J Clin Invest 2001; 108: 1247-1252.

3. Rabinovitch A, Suarez-Pinzon WL. Cytokines and their roles in pancreatic islet beta-cell destruction and insulin-dependent diabetes mellitus. Biochem Pharmacol 1998; 55: 1139-1149.

4. Bach JF. Therapeutic strategies in autoimmune diseases: the search for tolerance induction. Transplant Proc 1994; 26: 3188-3190.
5. Pietropaolo M, Pugliese A. The target organ: embryology, biochemistry and physiology. In: Eisenbarth GS, Lafferty KJ (eds.). Type 1 diabetes. Molecular, cellular and clinical immunology. Oxford University Press, New York 2000; 53-75.

6. Tisch R, McDevitt H. Insulin-dependent diabetes mellitus. Cell 1996; 85: 291-297.

7. Kikutani H, Makino S. The murine autoimmune diabetes model: NOD and related strains. Adv Immunol 1992; 51: 285-322.

8. Cutler RR, Wilson P. Antibacterial activity of a new, stable, aqueous extract of allicin against methicillin-resistant Staphylococcus aureus. Br J Biomed Sci 2004; 61: 71-74.

9. Cañizares P, Gracia I, Gómez LA, et al. Thermal degradation of allicin in garlic extracts and its implication on the inhibition of the in-vitro growth of Helicobacter pylori. Biotechnol Prog 2004; 20: 32-37.

10. Park SY, Cho SJ, Kwon HC, et al. Caspase-independent cell death by allicin in human epithelial carcinoma cells: involvement of PKA. Cancer Lett 2005; 224: 123-132.

11. Oommen S, Anto RJ, Srinivas G, Karunagaran D. Allicin (from garlic) induces caspase-mediated apoptosis in cancer cells. Eur J Pharmacol 2004; 485: 97-103.

12. Patya M, Zahalka MA, Vanichkin A, et al. Allicin stimulates lymphocytes and elicits an antitumor effect: a possible role of p21ras. Int Immunol 2004; 16: 275-281.

13. Davis SR. An overview of the antifungal properties of allicin and its breakdown products - the possibility of a safe and effective antifungal prophylactic. Mycoses 2005; 48: 95-100.

14. Siddique YH, Afzal M. Antigenotoxic effect of allicin against SCEs induced by methyl methanesulphonate in cultured mammalian cells. Indian J Exp Biol 2004; 42: 437-438.

15. Lang A, Lahav M, Sakhnini E, et al. Allicin inhibits spontaneous and TNF-alpha induced secretion of proinflammatory cytokines and chemokines from intestinal epithelial cells. Clin Nutr 2004; 23: 1199-1208.

16. Ghazanfari T, Hassan ZM, Ebrahimi M. Immunomodulatory activity of a protein isolated from garlic extract on delayed type hypersensitivity. Int Immunopharmacol 2002; 2: 1541-1549.

17. Rizwan Ashraf MP, Khan RA, Ashraf I. Effects of garlic on blood glucose levels and $\mathrm{HbA} 1 \mathrm{c}$ in patients with type 2 diabetes mellitus. J Med Plants Res 2011; 5: 2922-2928.

18. Birdee GS, Yeh G. Complementary and alternative medicine therapies for diabetes: a clinical review. Clin Diabet 2010; 28 : $147-155$.

19. Liu CT, Hse H, Lii CK, et al. Effects of garlic oil and diallyl trisulfide on glycemic control in diabetic rats. Eur J Pharmacol 2005; 516: $165-173$.

20. Liu CT, Wong PL, Lii CK, et al. Antidiabetic effect of garlic oil but not diallyl disulfide in rats with streptozotocin-induced diabetes. Food Chem Toxicol 2006; 44: 1377-1384.

21. Mustafa SS, Eid NI, Jafri SA, et al. Insulinotropic effect of aqueous ginger extract and aqueous garlic extract on the isolated perfused pancreas of streptozotocin induced diabetic rats. Pakistan J Zool 2007; 39: 279-284.

22. Eidi A, Eidi M, Esmaeili E. Antidiabetic effect of garlic (Allium sativum L.) in normal and streptozotocin-induced diabetic rats. Phytomedicine 2006; 13: 624-629.

23. Rerup CC. Drugs producing diabetes through damage of the insulin secreting cells. Pharmacol Rev 1970; 22: 485-518.

24. Junod A, Lambert AE, Stauffacher W, Renold AE. Diabetogenic action of streptozotocin: relationship of dose to metabolic response. J Clin Invest 1969; 48: 2129-2139.

25. Gurney AM, Howarth FC. Effects of streptozotocin-induced diabetes on the pharmacology of rat conduit and resistance intrapulmonary arteries. Cardiovasc Diabetol 2009; 8: 4.

26. Notkins AL, Lernmark A. Autoimmune type 1 diabetes: resolved and unresolved issues. J Clin Invest 2001; 108: 1247-1252.

27. Chandrashekar PM, Venkatesh YP. Identification of the protein components displaying immunomodulatory activity in aged garlic extract. J Ethnopharmacol 2009; 124: 384-390. 
28. Lamm DL, Riggs DR. Enhanced immunocompetence by garlic: role in bladder cancer and other malignancies. J Nutr 2001; 131: 1067S-1070S

29. Singh VK, Sharma PK, Dudhe R, et al. Immunomodulatory effects of some traditional medicinal plants. J Chem Pharm Res 2011; 3: 675-684.

30. Clement F, Pramod SN, Venkatesh YP. Identity of the immunomodulatory proteins from garlic (Allium sativum) with the major garlic lectins or agglutinins. Int Immunopharmacol 2010; 10: 316-324.

31. Liu CT, Wong PL, Lii CK, et al. Antidiabetic effect of garlic oil but not diallyl disulfide in rats with streptozotocin-induced diabetes. Food Chem Toxicol 2006; 44: 1377-1384.

32. Thomson M, Al-Amin ZM, Al-Qattan KK, et al. Anti-diabetic and hypolipidaemic properties of garlic (Allium sativum) in streptozotocin-induced diabetic rats. Int J Diabet Metab 2007; 15: 108-115.

33. Bokaeian M, Nakhaee A, Moodi B, et al. Effects of garlic extract treatment in normal and streptozotocin diabetic rats infected with Candida albicans. Indian J Clin Biochem 2010; 25: 182-187.

34. Mahesar H, Bhutto MA, Khand AA, et al. Garlic used as an alternative medicine to control diabetic mellitus in Alloxan-induced male rabbits. Pak J Physiol 2010; 6: 39-41.

35. Khayatnouri M, Bahari K, Safarmashaei S, et al. Study of the effect of gliclazide and garlic extract on blood sugar level in STZinduced diabetic male mice. Adv Environment Biol 2011; 5: 1751-1755.

36. Calvo RM, Forcen R, Obregon MJ, et al. Immunohistochemical and morphometric studies of the fetal pancreas in diabetic pregnant rats. Effects of insulin administration. Anat Rec 1998; 251: 173-180.

37. Goronzy JJ, Weyand CM. The innate and adaptive immune systems. In: Goldman L, Ausiello D (eds.). Cecil Medicine. 23 rd ed. Saunders Elsevier, Philadelphia 2007.

38. Bangstad HJ, Danne T, Deeb L, et al. Insulin treatment in children and adolescents with diabetes. Pediatr Diabetes 2009; 10 Suppl 12: 82-99.

\section{Address for correspondence}

\section{Muhamed Osman PhD}

Centre of Pathology, Diagnostic and Research Laboratory Faculty of Medicine, Universiti Teknologi MARA (UiTM) Sg. Buloh Campus, 47000 Sg Buloh

Selangor, Malaysia

e-mail: mtosman2004@gmail.com 